\title{
RESULTS AND METHODS IN THE RADIOCARBON DATING OF POTTERY
}

\author{
R. E. M. HEDGES ${ }^{1}$ CHEN TIEMEI $I^{2}$ and R. A. HOUSLEY ${ }^{1}$
}

ABSTRACT. The main problem with dating pottery by radiocarbon is that many different carbon sources, of different radiocarbon age, may contribute to the potsherd carbon content. Also, the process of firing is liable to destroy information that might help separate possible sources. We describe several pottery dating projects in which we have dated separate fractions (such as humics, lipids and classes of residual carbon). Although in some cases consistency between results is sufficient to accept that this approach can give a credible date, in other cases, no date has been possible, and general conclusions are difficult to make.

\section{INTRODUCTION}

The problems inherent in dating pottery have received fresh appraisal (De Atley 1980; Gabasio et al. 1986; Johnson et al. 1986; Johnson et al. 1988), in part stimulated by the possibilities of dating selected fractions by accelerator mass spectrometric (AMS) methods. Although many potential sources of carbon in surviving potsherds can be suggested, any given ceramic fabric in context is likely to present particular sources, and these need to be addressed through experiment. In this paper, we summarize several of our pottery-dating projects, including two in which we took a rather systematic approach to dating different fractions. In general, the results reflect the difficulty in isolating fractions that represent correctly the radiocarbon age of the pottery, but they also show that, if enough effort is made (supposing the pottery dating to be important enough), a fairly reliable date can be obtained.

\section{THE SOURCES OF CARBON IN POTTERY}

1. A pottery date presupposes reference either to the manufacture or the use of the pot. Residual carbon contemporary with the manufacture is most likely to be included with the temper and to have survived oxidation during firing. Another possibility is the absorption of soot and/or smoke during firing in reduced conditions. Carbon dating the use of the pot could result from subsequent external soot deposition, internal deposits of food or related residues, or the absorption of stable compounds associated with food storage such as lipids or proteins. There is no guarantee that a given sherd will contain appreciable quantities of any of these materials, however.

2. The material composing the potsherd may already contain carbon before manufacture. In particular, most clays contain appreciable amounts of carbon of "geological" age, which may or may not be oxidized in firing (Johnson et al. 1988). Model experiments have shown (Gabasio et al. 1986) that some differentiation between temper-derived organic content and clay-derived geological content could be made by controlling the temperature of combustion, the temper contribution being the more easily oxidized. Carbonates in both clay and temper are another, but easily differentiated, source.

3. The burial context of the potsherd also can contribute carbonaceous compounds through absorption of mobile material such as humic acids. Although undoubtedly present in potsherds, humic acids and related materials tend to reflect the date of the burial stratum (Batten et al. 1986), and often do not seriously alter the dating of the sherd. Good evidence indicates that lipids are not

${ }^{1}$ Oxford Radiocarbon Accelerator Unit, Research Laboratory for Archaeology and the History of Art, Oxford University, 6 Keble Road, Oxford OX1 3QJ, UK

${ }^{2}$ Department of Archaeology, Peking University, 100871 Beijing, Peoples Republic of China 
appreciably mobile between soil and sherd (Heron, Evershed \& Goad 1991). Bacterial activity, especially if the sherd was buried in an organic-rich deposit, may complicate the picture.

The relative contribution of (2) and (3) will depend upon the carbon content of (1), so that dating is much more likely to be reliable if the potsherd can be shown to contain large amounts of carbon that are probably derived from manufacture or use.

\section{STRATEGY FOR DATING PROGRAMS}

We have undertaken to date potsherds that are rich in carbon, or that have a particularly high archaeological value. No examples of known-age material have been studied; such a study, to have general relevance, would have to be very wide-ranging. In most cases, an archaeological context allowed us to evaluate the date (although with the danger of a circular argument); otherwise, evaluation must be by internal consistency of sherds, fractions or stratigraphy.

We discuss the following dating projects in turn:

Starčevo - eight potsherds from several sites belonging to the Starčevo culture (Neolithic) in Serbia, Yugoslavia. The temper consisted of chaff or dung, which had not been completely burned out because of a low firing temperature. The expected age was ca. 7000 BP (Datelist 5 - Gowlett et al. 1987).

China I - two early Neolithic sites, Pengdoushan (Hunan Province) and Zenpyan (Guangxi Province). We studied these because other radiocarbon dates from the sites had given unexpectedly early dates. Confirmation from dates directly on the pottery would be valuable. We dated several fractions each of two sherds from each site (Datelist 8 - Hedges et al. 1988).

China II - two additional sherds from Pengdoushan, as well as four sherds from Hujiawochan (also Hunan Province). The China II project strategy built on the experience from the China I project (Datelist 13 - Hedges et al. 1991b).

Ban Don Ta Phet - an Iron Age site in western Thailand with very little clearly associated organic material. Most of the material culture is either unique to the site (ceramics, iron, bronzes, glass beads) or are prestige items (jade, agate and carnelian beads) traded from India and Vietnam whose age is only poorly known. The sherds are rice-tempered (Datelist 11 - Hedges et al. 1990).

Non Nok Tha - a site in northeast Thailand with sherds of rice-tempered pottery. We dated sherds from two phases (Early and Middle periods), with one date on a carbonized rice grain (Datelist 13 - Hedges et al. 1991b).

Taperinha - a shell mound site near Santarem, in the Brazilian Amazon. Roosevelt et al. (1991) measured freshwater shells, charcoal and pottery. We analyzed two fractions from several sherds suspected to have an early date.

Bloodroot, Georgia, USA - soot encrustation from the outside of a single cordmarked sherd, thought to belong to the Late Woodland /Early Mississippian periods (AD 800-1200). Only one other date from the site is available (Datelist 12 - Hedges et al. 1991a).

Jenderam-Hilar, Selangar, Malaysia - rare open Neolithic site with evidence of occupation. Samples are from distinctive three-legged, cordmarked tripod pottery. We dated three sherds from samples of adhering charred food remains. Comparable dates are only very indirectly associated (Datelist 9 - Hedges et al. 1989). 


\section{ChEMiCAL PRETREATMENT AND THE SELECTION OF FRACTIONS}

We isolated the following fractions:

Coating - where a carbonaceous deposit (such as soot or food residue) is apparent. The treatment of this is mechanical removal, followed by diluted acid/alkali/acid washing (i.e., the standard treatment for charcoal, though often applied more gently).

Temper - on occasion, large $(0.5-2 \mathrm{~mm})$ carbonaceous fragments can be identified in the fabric of a crushed sherd. This is rare and depends upon the extent of oxidation during firing. (Often only the imprint remains, with perhaps traces of siliceous ash as a pseudomorph.) The carbon fragments can be excavated painstakingly, and are then treated as for charcoal, above.

Lipid - originally, lipids were extracted by ultrasonication in chloroform/methanol, but we have found Soxhlet extraction in acetone to be more effective. The acetone is evaporated, and the lipids combusted without further separation.

Humics - the crushed sherd, after acetone extraction, is treated with acid (dilute $\mathrm{HCl}$ to remove carbonates) and then extracted with $\mathrm{NaOH}$. Humics are precipitated from the extract with acid.

Residue - i.e., the crushed sherd fabric after the above extractions. Different size fractions may be distinguished.

HF Digest - Treatment of the residue with $40 \% \mathrm{HF}$ or $\mathrm{HF}+\mathrm{HCl}$, until no further dissolution. This reduces the solid residue to typically about $5-10 \%$ of the original. The carbon content of the HF residue can be quite high (up to $30 \%$ or so), but more usually is raised to $1-5 \%$. Thus, the residue is not pure carbon. Again, grain-size fractions may be distinguished.

\section{Discussion of Fractions:}

Coating - not all apparent carbonaceous residues contain appreciable carbon. Rarely, if ever, can a specific compound be extracted from the coating for radiocarbon measurement, and the predominant material is a grade of char. This is obviously susceptible to contamination by, e.g., soil humics, unless the elemental carbon content is high enough to withstand prolonged extraction by alkali. (Much the same applies to the dating of, e.g., charred seeds, however.)

Temper - whereas microscopic examination frequently indicates the use of temper with high organic content (e.g., rice straw, chopped dung), the survival of charred material from the temper in particulate form is quite rare. Certainly, when sufficient material is excavated for dating (up to $1 \mathrm{mg}$ carbon), microscopic excavation for about a day per sample was required. This approach seems to be more effective than attempting to dissolve the whole matrix leaving large carbon particles.

Lipid - many sherds contain extractable lipid at the level of $0.02-0.4 \%$. Heron, Evershed and Goad (1991) have shown that, as expected, lipids in potsherds are rather immobile. In their study, the background level in the soil was less than $100 \mathrm{ppm}$. Thus, very low concentrations of lipids in potsherds may be from infiltrating soil, or possibly microorganisms.

Residue - this is likely to include: 1) remaining carbon from organic temper; 2) remaining carbon from the original clay; 3 ) intrusive soil material, rootlets, etc.; and 4) possibly clay-humic complexes. 1) is likely to be dominant in a reasonably high carbon-containing sherd. The conditions for preservation of 1) are also conducive to 2). We have attempted to differentiate between them by analyzing different size fractions, arguing that carbon from temper would have a larger grain 
size. This approach (mainly for China I and II) has not proved to be especially successful. On the other hand, if different size distributions give different dates, this at least indicates the existence of a problem. Intrusive soil material is often released during acid/alkali cleaning, and, on occasion, can be collected for analysis.

HF Digested Residue - partly, it is convenient to concentrate the carbon content in the residue; partly, the action of $\mathrm{HF}$ is to make soluble a surprising quantity of clay-bound humic material. Attempts to divide the HF-digested fraction into particle-size fractions were made for China I, but the results are not easily interpreted. A fuller account of the results than is presented here can be found in Hedges et al. (1988). The extent to which carbon is concentrated in HF digestion depends partly on the sherd mineralogy, and partly on the persistence of laboratory effort. Table 1 summarizes the projects and fractions.

TABLE 1. Summary of Projects and Fractions

\begin{tabular}{lcccccc}
\hline & \multicolumn{7}{c}{ Fraction } \\
\cline { 2 - 7 } Site & Coating & Temper & Lipid & Humics & Residue & HF digest \\
\hline Starčevo & - & - & - & + & + & - \\
China I & - & - & + & + & + & + \\
China II & - & + & + & + & - & + \\
Ban Don Ta Phet & - & - & - & - & + & + \\
Non Nok Tha & - & - & - & - & - & + \\
Taperinha & {[]} & - & - & + & - & + \\
Bloodroot & + & - & - & - & - & - \\
Janderam Hilam & + & - & - & - & - & - \\
\hline
\end{tabular}

\section{RESULTS AND DISCUSSION}

Tables 2-11 list individual project results. See Figure 1 for a plot of the dates from all the sites.

TABLE 2. Starčevo

\begin{tabular}{lll}
\hline OxA no. & Sample & ${ }^{14} \mathrm{C}$ age $(\mathrm{yr} \mathrm{BP})$ \\
\hline 558 & Orange semi-fineware from Banja (residue) & $9310 \pm 140$ \\
633 & Humic acid from OxA-558 & $4860 \pm 120$ \\
559 & Dark monochrome fineware from Grivac (residue) & $8760 \pm 180$ \\
634 & Humic acid from OxA-559 & $6650 \pm 130$ \\
368 & Yellow-tan coarse barbotine body sherd from Vinca (residue) & $7230 \pm 170$ \\
369 & Humic acid from OxA-368 & $7040 \pm 170$ \\
556 & Coarseware sherd (residue) & $7400 \pm 200$ \\
557 & Coarseware sherd (residue) & $7350 \pm 150$ \\
560 & Sherd (residue) & $8250 \pm 160$ \\
561 & Coarseware sherd (residue) & $8080 \pm 130$ \\
562 & Semi-fineware sherd (residue) & $7160 \pm 140$ \\
\hline
\end{tabular}

In all cases, the residue is older than the humic component, and in many cases, is older than the archaeologically expected date. This is particularly true for the finer wares, with lower carbon contents. In these cases, the residue date appears to have been increased by incorporating geological 
carbon, whereas the humic dates clearly can be seriously too young (e.g., OxA-633). Where humic and residue dates agree, the combined date is consistent with the archaeologically expected date.

TABLE 3. China I - Pengdoushan, Hunan

\begin{tabular}{lll}
\hline OxA no. & Sample & ${ }^{14} \mathrm{C}$ age $(\mathrm{yr} \mathrm{BP})$ \\
\hline 1274 & Lipids & $6850 \pm 100$ \\
1275 & 'Humic acids' and inorganic material & $7770 \pm 80$ \\
1276 & Cleaned ceramic & $9700 \pm 80$ \\
1278 & Fine particles, ?intrusive clay $<0.7-\mu \mathrm{m}$ diameter & $8220 \pm 100$ \\
1279 & Coarse particles, ?intrusive silt and clay & $3780 \pm 80$ \\
1280 & $>500-\mu \mathrm{m}$ diameter (HF) & $9500 \pm 180$ \\
1281 & $<500-\mu \mathrm{m}$ diameter, $>1.6-\mu \mathrm{m}$ diameter (HF) & $7660 \pm 90$ \\
1282 & $<500-\mu \mathrm{m}$ diameter, $>0.7-\mu \mathrm{m}$ diameter (HF) & $8210 \pm 90$ \\
1273 & $<0.7-\mu \mathrm{m}$ diameter $(\mathrm{HF})$ & $8800 \pm 300$ \\
\hline
\end{tabular}

TABLE 4. China I - Zengpiyan Cave, Guangxi

\begin{tabular}{llc}
\hline OxA no. & Sample & ${ }^{14} \mathrm{C}$ age $(\mathrm{yr} \mathrm{BP})$ \\
\hline 1268 & 'Fulvic acids' & $8500 \pm 250$ \\
1269 & Cleaned ceramic & $8210 \pm 80$ \\
1270 & Intrusive silt and clay & $9520 \pm 100$ \\
1271 & Particles $>1.6 \mu \mathrm{m}(\mathrm{HF})$ & $9080 \pm 120$ \\
1272 & Particles $<1.6 \mu \mathrm{m}$ (HF) & $6650 \pm 110$ \\
2730 & Lipids & $7900 \pm 110$ \\
\hline
\end{tabular}

Only rough conclusions can be drawn. As noted above, the different size fractions reveal only that the residues contain carbon with a range of ages. Possibly, the results reflect random sampling from the small number of different-age particles, especially when large. The dates bracketed by the humic or fulvic fractions and the consensus of the residue dates (before or after HF digestion) suggest a date of $8000-9000 \mathrm{BP}$, which is consistent with dated charcoal from the site, and helps to confirm the contemporaneity of the pottery. The two lipid dates appear to be a little younger.

TABLE 5. China II - Pengdoushan, Hunan

\begin{tabular}{llc}
\hline OxA no. & Sample & ${ }^{14} \mathrm{C}$ age (yr BP) \\
\hline 2210 & Carbonized rice straw as temper in pottery, Sherd I & $7550 \pm 90$ \\
2278 & Lipid extracted with acetone, Sherd I & $13,030 \pm 140$ \\
2211 & Humic acid extracted with NaOH, Sherd I & $7300 \pm 90$ \\
2212 & HCl and NaOH cleaned pottery, Sherd I & $8300 \pm 80$ \\
2213 & Carbon in matrix after HF etching, Sherd I & $8950 \pm 80$ \\
2214 & Carbonized rice straw as temper in pottery, Sherd II & $7040 \pm 140$ \\
2279 & Lipid extracted with 'analar'-grade acetone, Sherd II & $19,570 \pm 240$ \\
2215 & Humic acid extracted with NaOH, Sherd II & $7390 \pm 80$ \\
2216 & HCl and NaOH cleaned pottery, Sherd II & $8050 \pm 80$ \\
2217 & Elemental carbon in matrix after HF etching, Sherd II & $8240 \pm 80$ \\
\hline
\end{tabular}


TABLE 6. China II - Hujiawochan, Hunan

\begin{tabular}{llc}
\hline OxA no. & Sample & ${ }^{14} \mathrm{C}$ age (yr BP) \\
\hline 2731 & Carbonized rice-straw temper, Sherd I & $6580 \pm 90$ \\
2732 & Lipid extracted with acetone, Sherd I & $9520 \pm 90$ \\
2218 & Carbonized rice-straw temper, Sherd II & $6219 \pm 90$ \\
2280 & Lipid extracted with acetone, Sherd II & $3930 \pm 80$ \\
2219 & Humic acids extracted with NaOH, Sherd II & $6500 \pm 80$ \\
2220 & Carbon in matrix after HF etching, Sherd II & $7370 \pm 80$ \\
2222 & Carbonized rice-straw temper, Sherd III & $6310 \pm 100$ \\
2281 & Lipid extracted with acetone, Sherd III & $3720 \pm 80$ \\
2223 & Humic acids extracted with NaOH, Sherd III & $6520 \pm 80$ \\
2224 & Carbon in matrix after HF etching, Sherd III & $7170 \pm 80$ \\
2733 & Carbonized rice-straw temper, Sherd IV & $6350 \pm 170$ \\
\hline
\end{tabular}

With the exception of the lipid dates, these fractions show a fairly consistent dating pattern. The temper fraction (which would be expected to be the most reliable) is generally bracketed between the humic and the residue dates. (The exception, OxA-2214, was only $0.1 \mathrm{mg}$ carbon, and the greater possible level of laboratory contamination may easily explain why this date is younger in the sequence.) The Pengdoushan sherds confirm and refine the sherd dating of China I, and an overall date for Pengdoushan ( 2 sherds) of 7500-8250 can be inferred. These samples are the earliest Neolithic pottery in Hunan. For Hujiawochan, three sherds date to 6200-6800 BP.

The lipid dates are puzzling. We now suspect contamination by silicone grease for OxA-2278 and -2279. These were the first to be extracted, and had anomalously large negative $\delta^{13} \mathrm{C}$ values $\left(\delta^{13} \mathrm{C}\right.$ for silicone grease was measured at $c a .-40 \%$ ). Lipid fractions were analyzed (using GC and $\mathrm{GC} / \mathrm{MS}$ ), but failed to disclose any unexpected compounds in large amounts. (Silicone grease is not expected to have been evident in the chromatograms.) Most of the volatiles (after saponification and derivatization) consist of the common long-chain (C16-20) fatty acids and related alkanes. We found a surprising level of plasticizer (as phthalate), although not enough to invalidate the dates. While we now suspect two old dates are due to a specific form of laboratory contamination, we can find no explanation for the surprisingly and consistently young dates of OxA-2280 and -2281.

TABLE 7. Ban Don Ta Phet

\begin{tabular}{llc}
\hline OxA no. & Sample & ${ }^{14} \mathrm{C}$ age $(\mathrm{yr} \mathrm{BP})$ \\
\hline 2012 & BDTP (60) 1224, HF treated & $2280 \pm 70$ \\
2013 & BDTP (78) 3360b, HF treated & $2320 \pm 80$ \\
2014 & BDTP (59) 1480, HF treated & $2210 \pm 70$ \\
2015 & BDTP (65) 1578, HF treated & $2260 \pm 80$ \\
2051 & BDTP (60) 1224, residue & $2680 \pm 70$ \\
2052 & BDTP (78) 3360b, residue & $2510 \pm 70$ \\
2053 & BDTP (59) 1480, residue & $2650 \pm 70$ \\
2054 & BDTP (65) 1578, residue & $2460 \pm 70$ \\
\hline
\end{tabular}

No macroscopic organic temper seems to have survived in these sherds. Two fractions, the residue with and without HF treatment, were dated, and gave consistent differences. It is very difficult to explain why the HF fraction should be younger; however, the younger set of consistent dates is favored archaeologically. The total carbon level is reasonably high. 
TABLE 8. Non Nok Tha

\begin{tabular}{lll}
\hline OxA no. & Sample & ${ }^{14} \mathrm{C}$ age $(\mathrm{yr} \mathrm{BP})$ \\
\hline 2383 & Sherd with rice-husk imprint & $3650 \pm 90$ \\
2384 & Sherd with rice chaff & $3250 \pm 100$ \\
2385 & Sherd with husk imprint & $1110 \pm 70$ \\
2386 & Sherd with charred chaff & $1300 \pm 80$ \\
2387 & Sherd with rice-chaff & $2950 \pm 80$ \\
2388 & Sherd with rice-husk temper & $2880 \pm 80$ \\
2389 & Sherd with rice-husk temper & $2920 \pm 80$ \\
2390 & Sherd with rice-husk or chaff & $3285 \pm 80$ \\
2391 & Sherd with rice-husks & $1320 \pm 100$ \\
2393 & Sherd with charred rice-chaff in temper & $3065 \pm 70$ \\
\hline
\end{tabular}

Despite numerous imprints of rice-straw tempering, no organic remains of temper were recoverable. Several other fractions were obtained, including lipids and humics, but only one fraction, the HF-treated residue, has been dated. We have not yet had useful archaeological comment on these results. The range covered is consistent with the few other dates available for the Early and Middle periods, but a detailed stratigraphic picture has yet to be worked out. A single rice grain associated with a burial vessel was also dated, at $3065 \pm 70$ (i.e., the same as for OxA-2393), which strengthens the general validity of the dates. With but one fraction dated, and rather loose archaeological corroboration, the dates stand in need of additional confirmation. At present, they exemplify the uncertainties in pottery dating.

TABLE 9. Taperinha

\begin{tabular}{llc}
\hline OxA no. & Sample & ${ }^{14} \mathrm{C}$ age (yr BP) \\
\hline 2431 & $\begin{array}{l}\text { Soot from surface of sherd } \\
\text { (HF residue) } \delta^{13} \mathrm{C}=-28.1 \% 0\end{array}$ & $6590 \pm 100$ \\
2432 & $\begin{array}{l}\text { Soot from surface of sherd } \\
\text { (humic and fulvic acids) } \delta^{13} \mathrm{C}=-28.1 \% 0\end{array}$ & $6640 \pm 80$ \\
\hline
\end{tabular}

The sample was more in the nature of a coating, but a substantial quantity of inorganic material was also present. Most of the organic material, extracted into alkali, was insoluble in dilute acid, and thus, was treated as humic acid. A smaller fraction was treated as potsherd residue, and digest with HF. It is noteworthy that both fractions gave the same date (the humic fraction gave $3 \mathrm{mg}$ carbon; the HF residue gave $230 \mu \mathrm{g}$ ). The date obtained, which defines the earliest pottery in the Americas (Roosevelt et al. 1991), receives independent confirmation from a thermoluminescence date on the same sherd $(7110 \pm 1400)$ (Reference 581A36; Oxford Research Laboratory for Archaeology).

Further potsherds from related sites are in the course of radiocarbon dating.

TABLE 10. Bloodroot

\begin{tabular}{llc}
\hline OxA no. & Sample & ${ }^{14} \mathrm{C}$ age (yr BP) \\
\hline 2202 & Soot from surface of sherd, $\delta^{13} \mathrm{C}=-24.9 \% 0$ & $940 \pm 60$ \\
\hline
\end{tabular}

Obtained from one fraction, from a soot deposit which was high in carbon and relatively resistant to alkali. The date obtained is consistent with a fairly sharply defined archaeological expectation. 
TABLE 11. Jendaram Hilar

\begin{tabular}{llc}
\hline OxA no. & Sample & ${ }^{14} \mathrm{C}$ age (yr BP) \\
\hline 19321 & Tripod leg & $3660 \pm 80$ \\
19332 & Small sherd & $3090 \pm 60$ \\
19343 & Large sherd & $3010 \pm 70$ \\
\hline
\end{tabular}

These dates were obtained from three sherds with encrustations of apparent food remains. Archaeologically, the dates are entirely acceptable; however, stratigraphic and contextual control is weak.

\section{SUMMARY AND CONCLUSIONS}

The results reported document the occurrence of forms of carbon of different radiocarbon ages in pottery, and show that it is not always possible unequivocally to isolate a fraction bearing the archaeological date.

However, dates on five sherds from three sites confirm that an organic-rich coating, such as from soot or food, provides a fairly reliable sample. Even with such a sample, the validity of the date is greatly strengthened if two fractions, such as humics (i.e., alkali soluble, acid insoluble) and residual carbon, can be compared. We report just one result where this has been done.

The second type of sample of choice is surviving organic temper, when it can be removed from the sherd. Probably more study should be devoted to the means to accomplish this, now that the results of the China projects show very clearly how reliable such material is. It should be borne in mind that even here, with many more hours devoted to excavation of the temper than is usual, one of the samples weighed only $100 \mu \mathrm{g}$. As for coatings, the result receives much greater reliability if supported by dates from related fractions.

Failing these types of sample fraction, probably no other single sample type can be relied upon. However, a combination of humic and HF-digested residue probably allows most potsherds, if containing appreciable amounts of carbon (i.e., ca. $1 \%$ or more), to be dated to within about \pm 300 years. On the whole, we conclude that it is worth attempting to date pottery only if a radiocarbon date is both particularly important (i.e., worth the cost of two or more dates on fractions), and does not need to be particularly accurate. Perhaps this is a disappointing outcome of the effort put into dating different fractions, but it is not surprising. We believe the results reported here give some measure of the extent of likely error. We also hope this paper demonstrates some very good reasons for attempting the dating of pottery.

The validity of dating extracted lipids remains tantalizingly unproven. In nearly all the samples discussed here, including Non Nok Tha and Ban Don Ta Phet, 0.5-2 mg of lipid could be extracted relatively easily from about $20 \mathrm{~g}$ of potsherd. However, of the 7 lipid dates measured, 2 are (probably) seriously laboratory contaminated, 2 are much too young, whereas the remaining 3 are in reasonable but by no means in exact agreement with other data. Nor does further chemical analysis appear to offer very much help in assessing the likely origin of the lipid extract.

\section{ACKNOWLEDGMENTS}

We acknowledge financial support for the Radiocarbon Accelerator Unit from the Science and Engineering Research Council. We should also like to record the contribution to this work by our colleagues, C. Anglias, A. Bowles, C. Bronk, J. Foreman, M. Humm, P. Leach and S. Stoker. 

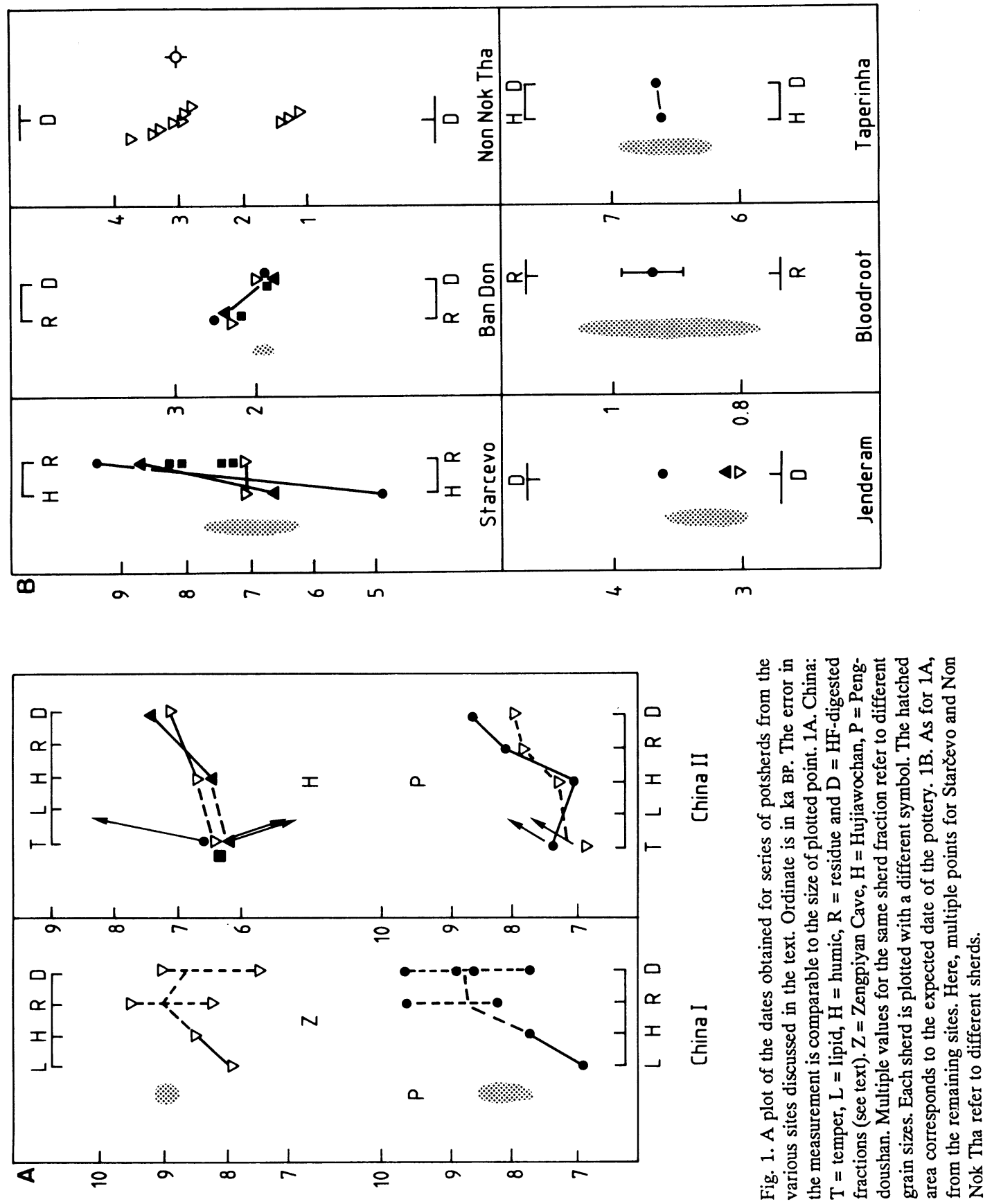


\section{REFERENCES}

Batten, R. J., Gillespie, R., Gowlett, J. A. J. and Hedges, R. E. M. 1986 The AMS dating of separate fractions in archaeology. In Stuiver, M. and Kra, R. S., eds., Proceedings of the 12 th International ${ }^{14} \mathrm{C}$ Conference. Radiocarbon 28(2A): 698-701.

De Atley, S. P. 1980 Radiocarbon dating of ceramic materials: progress and prospects. In Stuiver, M. and Kra, R. S., eds., Proceedings of the 10th International ${ }^{14} \mathrm{C}$ Conference. Radiocarbon 22(3): 987-996.

Gabasio, M., Evin, J., Arnal, G. B. and Andrieux, P. 1986 Origins of carbon in potsherds. In Stuiver, M. and $\mathrm{Kra}$, R. S., eds., Proceedings of the 12th International ${ }^{14} \mathrm{C}$ Conference. Radiocarbon 28(2A): 711718.

Gowlett, J. A. J., Hedges, R. E. M., Law, I. A. and Perry, C. 1987 Radiocarbon dates from the Oxford AMS system: Archaeometry Datelist 5.Archaeometry 29(1): 125-155.

Hedges, R. E. M., Housley, R. A., Bronk, C. R. and van Klinken, G. J. 1990 Radiocarbon dates from the Oxford AMS system: Archaeometry Datelist 11. Archaeometry 32(2): 211-237.

1991 a Radiocarbon dates from the Oxford AMS system: Archaeometry Datelist 12. Archaeometry 33(1): 121-134.

1991b Radiocarbon dates from the Oxford AMS system: Archaeometry Datelist 13. Archaeometry 33(2): 279-296.
Hedges, R. E. M., Housley, R. A., Law, I. A. and Bronk, C. R. 1989 Radiocarbon dates from the Oxford AMS system: Archaeometry Datelist 9. Archaeometry 31(2): 207-234.

Hedges, R. E. M., Housley, R. A., Law, I. A., Perry, C. and Hendy, E. 1988 Radiocarbon dates from the Oxford AMS system: Archaeometry Datelist 8. Archaeometry 30(2): 291-305.

Heron C., Evershed, R. P. and Goad, L. J. 1991 Effects of diagenesis and migration on organic residues associated with buried potsherds. Journal of Archaeological Science (in press).

Johnson, J. S., Clark, J., Miller-Antonio, S., Robins, D., Schiffer, M. B. and Skibo J. M. 1988 Effects of firing temperature on the fate of naturally occurring organic matter in clays. Journal of Archaeological Science 15: 403-414.

Johnson, R. A., Stipp, J. J., Tamers, M. A., Bonani, G. Suter, M. and Wölfli, W. 1986 Archaeologic sherd dating: Comparison of thermoluminescence dates with radiocarbon dates by beta counting and accelerator techniques. In Stuiver, M. and Kra, R. S., eds., Proceedings of the 12 th International ${ }^{14} \mathrm{C}$ Conference. Radiocarbon 28(2A): 719-725

Roosevelt, A. C., Housley, R. A., Imazio da Silveira, M., Maranca, S. and Johnson, R. 1991 Eighth millennium pottery from a prehistoric shell midden in the Brazilian Amazon. Science 254: 1621-1624. 